\title{
The regional feasibility of augmented local water storages
}

\author{
$\underline{\text { M.J. Nikkels }}^{\text {abc }}{ }^{\text {, P.J.T. van Bakel }}{ }^{\mathrm{d}}$, J.R. Delsman ${ }^{\mathrm{e}}$, P.G.B. de Louw $^{\mathrm{e}}$, P.R. van Oel ${ }^{\mathrm{a}}$, L.C.P.M. Stuyt ${ }^{\mathrm{f}}$, \\ P. Vellingag ${ }^{g}$ J. Velstra ${ }^{\text {h }}$ and P.J.G.J. Hellegers ${ }^{a}$
}

\author{
${ }^{a}$ Water Resources Management (WRM) group, Wageningen University, Wageningen, Netherlands \\ ${ }^{b}$ School of Land and Food, University of Tasmania, Hobart, Australia \\ 'Aequator Groen \& Ruimte, Harderwijk, Netherlands \\ ${ }^{d}$ De Bakelse Stroom, Wageningen, Netherlands \\ ${ }^{e}$ Department of Soil and Groundwater, Deltares, Utrecht, Netherlands \\ ${ }^{f}$ Department of Soil, Water and Land use, Alterra, Wageningen, Netherlands \\ ${ }^{g}$ Department of Climate change and adaptive land and water management, Alterra, Wageningen, \\ Netherlands \\ ${ }^{h}$ Acacia Water, Gouda, Netherlands \\ Email:melle.nikkels@,wur.nl
}

\begin{abstract}
Local water storages can contribute significantly to meet regional demands for water and offer governments a strategy for reducing or delaying investment in large-centralised water infrastructure. Local water storages include ponds, canals, drainage systems and subsurface aquifers. Augmentation of local water storages and determination of their regional feasibility is not fully understood. Cost-effectiveness, physical characteristics, interactions between measures and interactions with the national water system are of crucial importance here. Dutch national and regional water managers currently negotiate about water distribution and regional self-reliance. However, in the Dutch negotiation, the potential of local groundwater storage, as a way to overcome periods of drought, is generally underestimated.
\end{abstract}

In this study, we assessed the potential of local groundwater storage measures, regarding technical storage capacity (in cubic meters $\left(\mathrm{m}^{3}\right)$ ) and costs (euro/ha/year and euro/ $/ \mathrm{m}^{3}$ ), in a case study area in the Netherlands (Wieringen+Wieringermeerpolder) by means of a novel dynamic modelling method, called the Fresh Water Options Optimizer (FWOO).

The first results of the FWOO method show that Wieringen+Wieringermeerpolder is able to store between 35 million cubic meters $\left(\mathrm{Mm}^{3}\right)$ and $80 \mathrm{Mm}^{3}$ with the seven local groundwater storage measures that are taken into account. This is $80 \%$ to $180 \%$ of the summer demand, based on a water demand of $200 \mathrm{~mm}$ during the growing season. The costs for the combination of measures in Wieringen+Wieringermeerpolder are between 0.10 euro $/ \mathrm{m}^{3}$ and 0.13 euro $/ \mathrm{m}^{3}$.

The FWOO is not ready yet. Not all dynamics of augmenting local waters storage measures are (modelling wise) properly addressed. For example, temporal aspects of water supply and demand are not yet taken into account. Besides, preferences and needs of other water users (nature, industry, and urban areas) might lead to undiscovered options to store and reuse water. To inform regional water managers, efforts to compare the costs of local measures with centralized water storage and provision strategies are needed.

Although the model is still under improvement, these first results open new perspectives on the potential of regional self-reliance and should be taken into account during negotiations around water distribution between national and regional water managers.

Keywords: Fresh water supply management, scale issues, regional self-reliance, decision making 


\section{INTRODUCTION}

The pressure on fresh water supply increases in the (near) future, due to climatic and socio-economic changes. The risk of both drought and flooding is increasing. Droughts cause crop damage and can result in a decrease in farm income. Increasing differences between (temporal) water availability and demand can lead to tensions between actors.

Estimates within the scope of the Dutch Delta program indicate that the economic loss to the Dutch agricultural sector may reach 700 million euro in a current 'dry year' (probability of 1/10 year) with a precipitation deficit of more than $220 \mathrm{~mm}$ in summer. In an 'extreme dry year' (probability of 1/100 year), with a precipitation deficit of over $360 \mathrm{~mm}$ in summer, the economic loss to the agricultural sector may reach 1,800 million euros. Due to climatic change and socio-economic developments, the agricultural sector might face a loss of 700 million euro once every two years (Ministry of Infrastructure and the Environment \& Ministry of Economic Affairs, 2011).

Therefore, the local, regional, national and international water managers are cooperating to better manage the Dutch water system. The Dutch Delta Program Fresh Water (DPZW) explores approaches to sustain the water supply and to increase local self-reliance. Multiple strategies are explored, where central versus distributed storage and supply are considered. The DPZW identifies local groundwater storage as a partial solution but does not have clear insight into its potential to secure water during droughts. Despite this, the national and regional water managers are negotiating about water distribution and regional self-reliance.

Local water storages seem to have potential to secure the regional water availability. Examples of local water storages include ponds, canals, drainage systems and subsurface aquifers and can be complemented by technologies for recycling or treating water.

In order to compare central versus distributed (local) storage it is of crucial importance to know how much water can be stored, and how much this would cost. However, the potential for up scaling and the optimal mix of different local measures at the regional level is still unknown. Physical characteristics, interactions between measures and interactions with the national water system are of crucial importance here. Efforts are made by the 2030 Water Resources Group (2009) and Hellegers et al. (2013) to aggregate measures with the help of marginal cost curves but they do not take all the dynamics of augmentation into account. For that reason, a new method, called the Fresh Water Options Optimizer (FWOO), is under development (van Bakel et al., 2014).

Also, the financial feasibility of local measures is not fully identified. A cost-effectiveness analysis is performed to compare measures and to provide the costs of the FWOO outcomes.

The main aim of this paper is to study the potential regarding technical storage capacity and cost effectiveness of local fresh water storage as a way to overcome periods of drought. The hypothesis of this paper is: Groundwater storage has more potential than is reflected within the DPZW (2014).

The FWOO method is explained in section 2.1. Section 2.2 describes the test case location and section 2.3 clarifies the cost-effectiveness analysis. In section 3 the first results will be shown, to end with conclusions and discussion in section 4 , where the results will be used to assess the implications for national fresh water policy.

\section{TOWARDS FEASIBILITY DETERMINATION OF GROUNDWATER STORAGE MEASURES}

\subsection{FWOO}

A dynamic modelling method is under development and described by van Bakel et al. (2014). It calculates how much fresh water can technically be stored in a particular region. The method consists of six steps (Figure 1).

The FWOO method can be applied in different areas and with different local measures. For application in the Netherlands, we selected seven measures that store water in the subsurface (described in Table 1 and displayed in Figure 2). Most of them are in their pilot stage and related to the Knowledge for Climate ${ }^{1}$ trajectory.

\footnotetext{
${ }^{1}$ Knowledge for Climate was a Dutch research programme in the field of climate change and adaptation that ran from 2007 till 2014.
} 


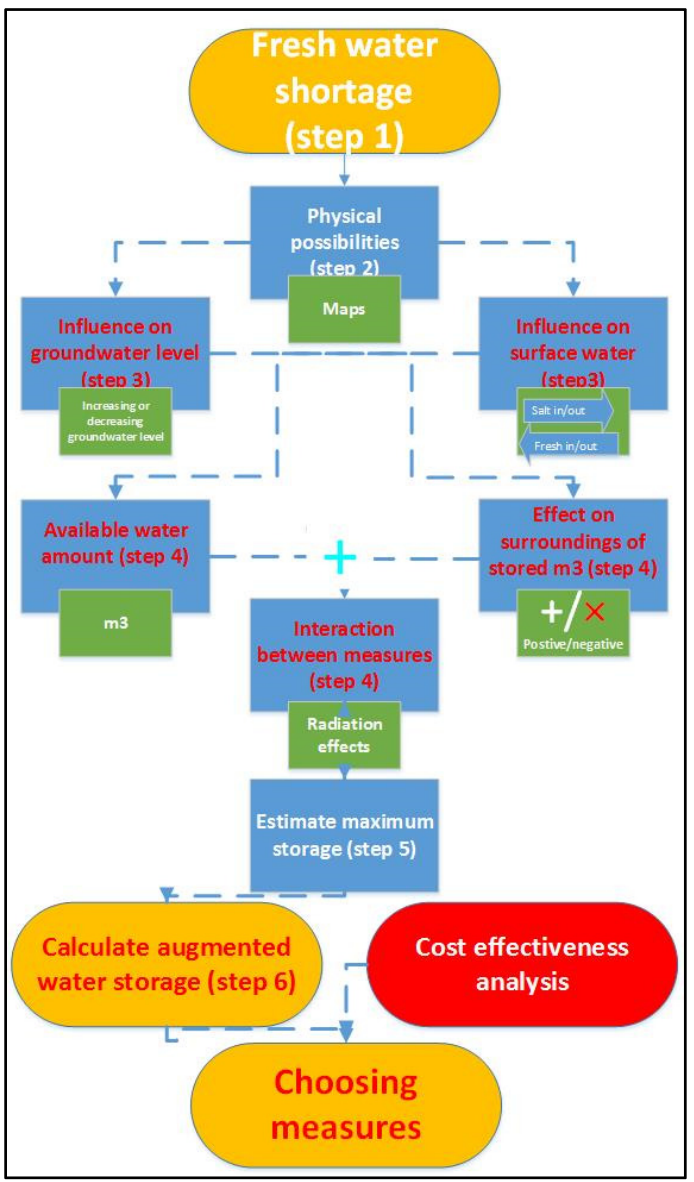

Figure 1. Stream flow diagram, based on the FWOO method.
1. Fresh water shortage analysis. In order to determine the added value of local measures, it is important to start with an analysis of the current and future fresh water shortage in the area. When there is drought related crop damage and the fresh water supply is, or will be, a bottleneck than the potential of alternative sources of fresh water should be studied.

2. Physical possibility maps. The second step is to examine the subsurface and the surface water system for various types of measures. Suitability of the subsurface is mapped, based on physical characteristics of the subsurface and the needs of the measures. These maps are used to identify where the subsurface is promising for a certain measure. The suitability ranges from very promising to not suitable.

3. Influence on (saline) upward groundwater flow, groundwater and surface water. Measures may indirectly affect the water system. This might lead to more or less (saline) seepage. Some measures require water supply in the period that the fresh water buffer is established. With other measures, the ground water level is increased in the winter, to infiltrate fresh water. There are also measures that discharge salt water into surface water.

4. Interaction between measures and intercation with the surrounding water system. Measures do not only affect the freshwater availability at the location to which the measure is applied, but can also affect the groundwater level and the surface waters in adjacent areas. When making choices between measures, understanding these spill overs is very relevant.

5. Estimate maximum storage. When it is likely that a measure can be successfully applied, the effect of the measure in that particular area is estimated. During this exercise, we worked with the estimates shown in Table 1. These estimations are based on pilot outcomes and expert judgement.

Several measures may be possible at one specific location. When the aim is to optimize fresh water storage, the measure which is most promising in terms of water storage and which has no undesirable side effects (step 4) is selected.

6. Calculate the water storage in the region. For each measure, the extra water availability at the beginning of the growing season is calculated. Local circumstances, for example soil type, have a large impact on the functionality of the measures and the amount of water that can be stored. Therefore, these numbers must be seen as rough estimates and as a generalized method to compare the measures.

For this analysis, an average soil porosity of 0.3 for measures below the water level or a phreatic storage capacity of 0.1 for measures that influence the water table are used to calculate the amount of stored water in $\mathrm{m}^{3}$. This leads to an estimation of extra available water in $\mathrm{m}^{3}$ per

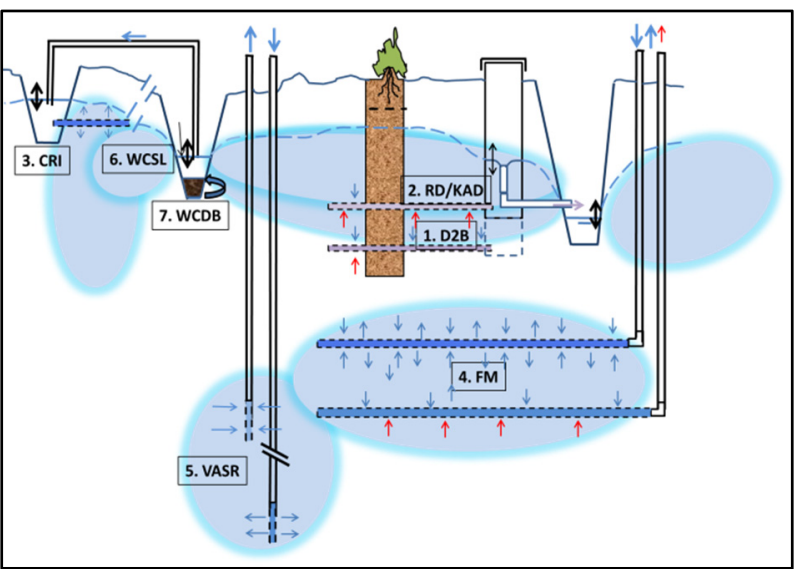

Figure 2. Water storage measures. Based on van Bakel et al. (2014). hectare as displayed in Table 1.

Note that the red text in Figure 3 means that the step is modelling-wise still under development. The costeffectiveness analysis is not part of the FWOO method. 
Nikkels M.J. et al., The regional feasibility of augmented local water storages

Table 1. The seven local water storage measure used in the FWOO method.

\begin{tabular}{|l|l|l|l|}
\hline Measure & Description of the seven local groundwater storage measures & $\begin{array}{l}\Delta \text { water } \\
\text { lens (m) }\end{array}$ & $\mathbf{m}^{\mathbf{3} / \mathbf{h a}}$ \\
\hline $\begin{array}{l}\text { 5. ASR Coastal } \\
\text { (VASR) }\end{array}$ & $\begin{array}{l}\text { brings rain water, which is collected in and on greenhouses, in the first aquifer. } \\
\text { Fresh water is infiltrated with a vertical tube and withdrawn by means of four } \\
\text { filters at different depths. }\end{array}$ & 1.4 & 4200 \\
\hline 4. Freshmaker (FM) & $\begin{array}{l}\text { increases an existing shallow fresh water bubble through infiltration of fresh } \\
\text { water by means of a horizontal tube. An underlying tube withdraws salty } \\
\text { groundwater. }\end{array}$ & 0.66 & 2000 \\
\hline $\begin{array}{l}\text { 3. Creek ridge } \\
\text { infiltration (CRI) }\end{array}$ & $\begin{array}{l}\text { increases the fresh water bubble in a creek ridge by increasing the groundwater } \\
\text { level through controlled drainage combined with infiltration of surface water. }\end{array}$ & 0.5 & 1500 \\
\hline $\begin{array}{l}\text { 1. Drains2buffer (D2B) } \\
\text { teepened controlled drainage so that the saline groundwater is discharged to } \\
\text { the ditches and the fresh water lens can grow with fresh water from } \\
\text { precipitation. }\end{array}$ & 0,3 & 900 \\
\hline $\begin{array}{l}\text { 2. Controlled Drainage } \\
\text { (CD) }\end{array}$ & $\begin{array}{l}\text { allows the drainage basis level to be adjusted throughout year. It provides the } \\
\text { possibility to increase the groundwater level to store water. }\end{array}$ & 0.3 & 300 \\
\hline $\begin{array}{l}\text { 6. Water conservation } \\
\text { with small weirs } \\
\text { (WCSL) }\end{array}$ & $\begin{array}{l}\text { by means of elevating the ditch bottoms, groundwater levels can be increased } \\
\text { with the same amount of surface water. Water will infiltrate into the plot, } \\
\text { which leads to extra storage in the groundwater. }\end{array}$ & 0.2 & 200 \\
\hline $\begin{array}{l}\text { 7. Water conservation } \\
\text { with ditch bottom } \\
\text { elevation (WCDB) }\end{array}$ & $\begin{array}{l}\text { Water levels in ditches are increased. This leads to a bigger buffer in the surface } \\
\text { water but also increases the groundwater level in its surrounding. }\end{array}$ & 0.15 & 150 \\
\hline
\end{tabular}

\subsection{Test case location}

The method has been applied in Wieringen+Wieringermeer, 2 regions located in the province North Holland with land use dominated by the agricultural sector. Wieringen is a former island at the North East corner of the province (Figure 1). With the construction of the Wieringermeer polder, it was connected to the mainland. Wieringen consist of both upward and downward seepage areas and has a very heterogeneous structured sub-soil. Potatoes, grains and flower bulb are predominant. The Wieringermeer polder is a highly productive polder, with a long history of water related stress. Land use in the Wieringermeer polder is very diverse with open ground agriculture, horticulture and greenhouses. Water demands are among the highest in North Holland, due to flushing and irrigation requirements. The polder is completely drained with a homogenous clayey top soil, but the sub-soil consists of various layers and even a fresh water lens in the southern tip of the polder.

Water provision is managed by the water board Hoogheemraadschap Hollands Noorderkwartier (HHNK). HHNK receives water from Lake IJssel and Lake Marker. Together, these lakes form the largest fresh water buffer in the Netherlands. Because the shallow fresh/brackish interface, due to salt water intrusion, the surface waters need to be flushed regularly. Under normal conditions, there is enough water available for flushing and irrigation. However, when droughts occur, ditches become too brackish and irrigation limits are put in place leading to costly water stress.

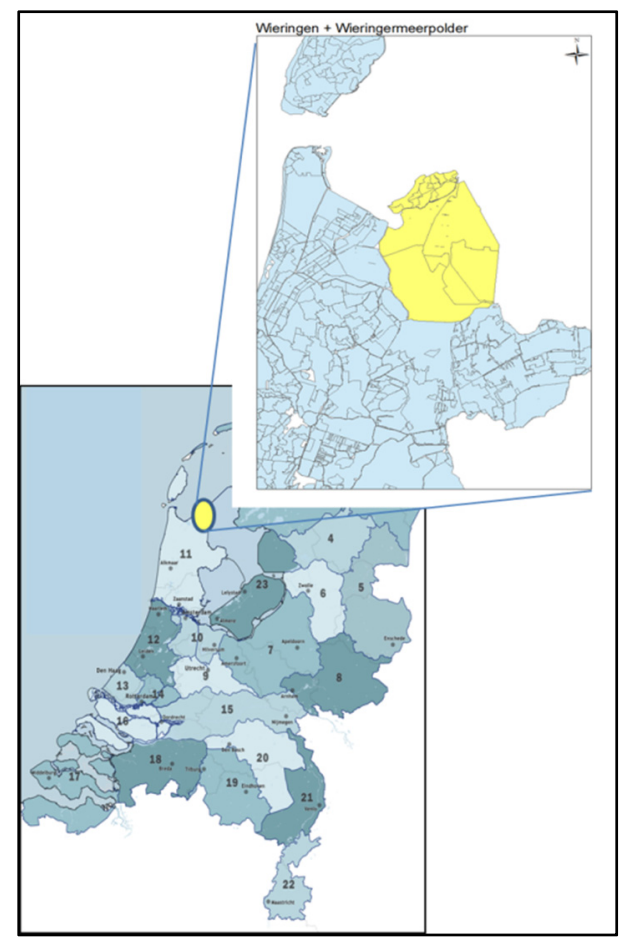

Figure 3. Test location, where HHNK is number 11 and Wieringen+Wieringermeer is yellow.

\subsection{Costs per $\mathbf{m}^{3}$ of the seven local water storage measures}

Costs for the seven measures (Table 1) have been estimated by e.g. Hekman and Jonge (2013) and Stuyt et al. (2014). Cost estimations include costs of implementation and exploitation. Cost estimations at the beginning of the pilot phase contain more uncertainties when compared to estimates after considerable experience of (executive) parties. Differences in the annual costs per hectare for the same measure may occur. This might 
be due to different unit costs, but also different life spans, the number of parameters and the discount rate on investment are of great influence on the calculated costs per $\mathrm{m}^{3}$. This makes comparisons between measures misleading. It can lead to false conclusions and conflicting advices. Therefore, a costs calculation method is introduced here to compare the costs-effectiveness of the various measures. Table 2 and 3 summarize the findings of the cost-effectiveness analysis. There are no costs for WCDB as this method only requires less maintenance of the ditch bottoms.

The calculated costs of the FWOO measures are social $\operatorname{costs}^{2}$ with no residual value ${ }^{3}$ and no external costs. This angle of approach to compare costs of measures is chosen for two reasons.

Firstly, HHNK and other Water boards are examples of management bodies focusing on societal tasks. Their optimal strategy should be the most beneficial for their management area/society.

Secondly, private costs ${ }^{4}$ are more difficult to calculate because of very case specific criteria such as the interest rate on the (possible) loan, income and tax construction and subsidies.

The costs of local measures are presented in euro/hectare/year and in euro $/ \mathrm{m}^{3}$, which allows comparison of the different costs of measures. This makes the comparison between the measures a "costs effectiveness analysis" when the measures are ranked (Berbel et al., 2011).

Certain costs are non-recurring, for example implementing costs, while other costs are recurring each year (exploitation costs). The exploitation costs include operational costs, maintenance costs and $2 \%$ of the implementation costs for unforeseen expenses when electric power devices are used. The annual costs are discounted to represent the Net Present Value (NPV) of future investments using a fixed discount rate.

A $5.5 \%$ discount rate has been used, as subscribed by the Dutch Central Planning Office (CPB) and the Netherlands Environmental Assessment agency (PBL) (Robijn \& Renes, 2013). The 5.5\% discount rate is under debate and might change in 2015 (Staf deltacommissaris, 2013). The discount rate decreases the current value of future investments. This is based on inflation $(2.5 \%)$ and the risks associated with adaptive measures $(3 \%)$.

One of the "risks" is on-going innovations. The research field of local fresh water buffering is subject to increasing attention and new insights and developments of new measures are common. Climatic changes and innovations will lead to new insights and adaptation measures. The high discount rate assures that smaller investments today, with short life spans, out-favour large investments with long time spans.

In this cost calculation a time horizon of 60 years is used, 3 times the life span with no residual value. Besides the 60 years, annual costs with a time horizon of 10 years are calculated to give estimation for the private costs. Also, the annual costs are presented when discounted with $2.5 \%$ (inflation) to show the sensitivity of the costs to a lower discount rate.

\section{RESULTS}

\subsection{First results of FWOO application}

The first results of the FWOO method, displayed in Figure 4, show that Wieringen+Wieringermeerpolder is able to store $37 \mathrm{Mm}^{3}$ with the local water storage measures that are taken into account. This is $80 \%$ of the summer demand, based on a water demand of 200 $\mathrm{mm}$ during the growing season. For this estimation we only selected a measure when the subsurface was "very promising" (step 2 of the FWOO method).

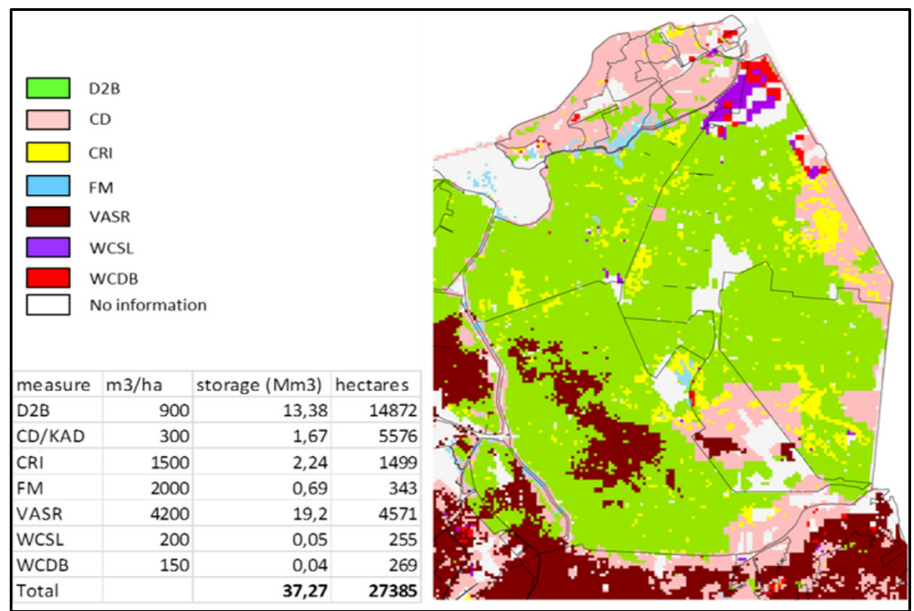

Figure 4. Results of the FWOO method.

\footnotetext{
2 Social costs are the total costs to society.

3 Value at the end of estimated life span.

${ }^{4}$ Costs to be covered by private land owners or water users.
} 
Nikkels M.J. et al., The regional feasibility of augmented local water storages

When we also selected measures when the subsurface was "promising" $80 \mathrm{Mm}^{3}$ or $180 \%$ of the summer demand could be stored with VASR (as this is the measure that can store most $\mathrm{m}^{3} / \mathrm{ha}$ ).

Drains2Buffer (light green) is predominant with 14,872 ha. However, with $13.4 \mathrm{Mm}^{3}$, it is not the measure storing most $\mathrm{m}^{3}$. ASR stores $19.2 \mathrm{Mm}^{3}$ when it is applied to 4,571 ha.

\subsection{Cost-effectiveness}

The costs/ha/year varies from 497 euro for the Freshmaker to 64 euro for WCSL (Table 2). Based on the water storage capacity of the different measures, the costs for the different measures can be calculated. Dividing the costs/ha by the storage capacity gives the costs $/ \mathrm{m}^{3}$. The results are shown in Table 3 .

The range of costs $/ \mathrm{m}^{3}$ is considerably less, because more expensive measures are able to store more water. The costs range from 0.07 euro $/ \mathrm{m}^{3}$ to 0.27 euro $/ \mathrm{m}^{3}$.

Table 2. Annual costs per hectare.

\begin{tabular}{|c|c|c|c|c|c|c|c|}
\hline & ASR & Freshmaker & $\begin{array}{l}\text { Creek ridge } \\
\text { infiltration }\end{array}$ & $\begin{array}{l}\text { Controlled } \\
\text { drainage }\end{array}$ & Drains2Buffer & WCSL & WCDB \\
\hline $\begin{array}{l}\text { costs/ha/year (60 years, } 5.5 \% \\
\text { discount rate) }\end{array}$ & $€ 312$ & $€ 497$ & $€ 109$ & $€ 82$ & $€ 82$ & $€ 64$ & \\
\hline $\begin{array}{l}\text { costs/ha/year ( } 60 \text { years, } 2.5 \% \\
\text { discount rate) }\end{array}$ & $€ 504$ & $€ 807$ & $€ 177$ & $€ 126$ & $€ 126$ & $€ 110$ & \\
\hline $\begin{array}{l}\text { costs/ha/year (10 years, } 5.5 \% \\
\text { discount rate) }\end{array}$ & $€ 1,000$ & $€ 1,586$ & $€ 353$ & $€ 293$ & $€ 293$ & $€ 183$ & \\
\hline $\begin{array}{l}\text { costs/ha/year (10 years, } 2.5 \\
\text { discount rate) }\end{array}$ & $€ 1,092$ & $€ 1,735$ & $€ 384$ & $€ 312$ & $€ 312$ & $€ 207$ & \\
\hline
\end{tabular}

In this comparison, ASR and creek ridge infiltration were the most cost-effective, both on the long and the short run, and with both a $2.5 \%$ and $5.5 \%$ discount rate. Controlled drainage and WCST are most cost effective. It depends on the discount rate which one of the two has the highest costs. This is due to lower exploitation costs but higher implementation costs for controlled drainage when compared with the WCST measure.

The annual costs of the local measures as calculated with the FWOO are 3.4 million euro, or 0.10 euro $/ \mathrm{m}^{3}$.

Table 3. Discounted costs per $\mathrm{m}^{3}$.

\begin{tabular}{|c|c|c|c|c|c|c|c|}
\hline & ASR & Freshmaker & $\begin{array}{l}\text { Creek ridge } \\
\text { infiltration }\end{array}$ & $\begin{array}{l}\text { Controlled } \\
\text { drainage }\end{array}$ & Drains2Buffer & WCSL & WCDB \\
\hline $\begin{array}{l}\text { costs } / \mathrm{m}^{3} \text { (60 years, } 5.5 \% \\
\text { discount rate) }\end{array}$ & $€ 0.07$ & $€ 0.25$ & $€ 0.07$ & $€ 0.27$ & $€ 0.09$ & $€ 0.32$ & \\
\hline $\begin{array}{l}\text { costs } / \mathrm{m}^{3} \text { ( } 60 \text { years, } 2.5 \% \\
\text { discount rate) }\end{array}$ & $€ 0.12$ & $€ 0.40$ & $€ 0.12$ & $€ 0.42$ & $€ 0.14$ & $€ 0.55$ & \\
\hline $\begin{array}{l}\text { costs } / \mathrm{m}^{3} \text { (10 years, } 5.5 \% \\
\text { discount rate) }\end{array}$ & $€ 0.24$ & $€ 0.79$ & $€ 0.24$ & $€ 0.98$ & $€ 0.33$ & $€ 0.91$ & \\
\hline $\begin{array}{l}\text { costs } / \mathrm{m}^{3} \text { (10 years, } 2.5 \% \\
\text { discount rate) }\end{array}$ & $€ 0.26$ & $€ 0.87$ & $€ 0.26$ & $€ 1.04$ & $€ 0.35$ & $€ 1.04$ & \\
\hline
\end{tabular}

\section{CONCLUSIONS AND DISCUSSION}

The overall conclusion is that groundwater storage measures have more potential in both storage and in costs than is currently displayed in the DPZW. This opens new perspectives on the potential of regional selfreliance and should be taken into account in the negotiations between the Delta Programme and the water management regions (such as HHNK).

The first results of the FWOO method show that Wieringen+Wieringermeerpolder is able to store $37 \mathrm{Mm}^{3}$ for 0.10 euro $/ \mathrm{m}^{3}$ with the seven local groundwater storing measures that are taken into account. This is $80 \%$ of the summer demand, based on a water demand of $200 \mathrm{~mm}$ during the growing season. Local freshwater storage measures are therefore a promising way to address freshwater security in this region. 
To increase the applicability of the method it is necessary to gain experience by applying the method in other regions. Therefore it is important to broaden the set of measures. The authors are working on physical suitability maps for Europe. Besides, the FWOO method will be applied in Spain. These results and experiences will lead to improvements in the method.

The amount of water, available for the plants at the time it is needed requires a more sophisticated calculation. With the blue measures in Table 1 (Freshmaker and ASR Coastal), stored water becomes available by means of pumps. Therefore, the stored water is more manageable than measures that supply extra water to the root zone (i.e. increase soil moisture). Besides, the recovery factor is influenced by many factors including leakage, infiltration, and soil resistance, pumping allocation and mixing of water bodies. In this test case, the local storages should be used to bridge periods of drought, where withdrawal of surface waters is restricted. These temporal aspects of water supply and demand need further research and are not yet taken into account.

Preferences and needs of other water users (nature, industry, and urban areas) might lead to undiscovered options to store and reuse water. To inform regional water managers, research to compare the costs of local measures with centralized water storage and provision strategies is needed.

Although the FWOO method is still under development, the experience so far open new perspectives on the potential of local water storage measures and might lead to unrevealed adaptation strategies towards regional self-reliance.

\section{ACKNOWLEDGMENTS}

The FWOO project was funded by STOWA, the knowledge centre of the regional water managers (mostly the Water Boards) in the Netherlands.

\section{REFERENCES}

2030 Water Resources Group. (2009). Charting Our Water Future, Economic frameworks to inform decisionmaking. Munich: McKinsey and Company.

Berbel, J., Martin-Ortega, J., \& Mesa, P. (2011). A Cost-Effectiveness Analysis of Water-Saving Measures for the Water Framework Directive: the Case of the Guadalquivir River Basin in Southern Spain. Water Resources Management, 25(2), 623-640. doi: 10.1007/s11269-010-9717-6

Hekman, A. J., \& Jonge, M. d. (2013). Flexibiliteit in regionaal waterbeheer, Verkenning naar mogelijkheden in het regionale watersysteem die bijdragen aan de integrale opgave van het Deltaprogramma IJsselmeergebied. Alkmaar: Grontmij.

Hellegers, P., Immerzeel, W., \& Droogers, P. (2013). Economic concepts to address future water supplydemand imbalances in Iran, Morocco and Saudi Arabia. Journal of Hydrology, 502, 62-67. doi: 10.1016/j.jhydrol.2013.08.024

Ministry of Infrastructure and the Environment, \& Ministry of Economic Affairs, A. a. I. (2011). Deltaprogramma 2012 - Werken aan de delta. Den Haag: Ministerie van Infrastructuur en Milieu, Ministerie van Economische Zaken, Landbouw en Innovatie.

Robijn, G., \& Renes, G. (2013). Algemene leidraad voor maatschappelijke kosten-batenanalyse. Den Haag: $\mathrm{CPB} / \mathrm{PBL}$.

Staf deltacommissaris. (2013). Deltaprogramma 2014, Kansrijke oplossingen voor opgaven en ambities Werk aan de delta. Den Haag: Ministery of Infrastructure and Environment \& Ministery of Economic affairs.

Stuyt, L. C. P. M., Bakel, P. J. T. v., Delsman, J., Massop, H. T. L., Kselik, R. A. L., Paulissen, M. P. C. P., . . Schipper, P. N. M. (2014), €ureyeopener 2.1: Zoetwatervoorziening Eureyeopener 2.1: Zoetwater voorziening Zuidwestelijke Delta en Drechtsteden. Wageningen: Alterra Wageningen UR

van Bakel, J., de Louw, P., Massop, H., Stuyt, L., Tolk, L., Velstra, J., . . . Nikkels, M. (2014). Methode voor het selecteren van lokale zoetwateroplossingen en het afwegen van hun effecten, Fresh Water Options Optimizer.

Zoetwater, D. (2014). Advies Deltaplan Zoetwater, Uitvoeringsprogramma bij de Voorkeursstrategie Zoetwater. Den Haag: Ministry of Infrastructure and the Environment and Ministry of Economic Affairs. 